\title{
Strategic Management in the Relationship between Competitiveness and Organizational Performance in MSMES of the Service Sector in Mexico
}

\author{
Marisol Sanchez-Guerrero ${ }^{1}$, Alejandro Arellano-Gonzalez ${ }^{2}$, Nidia J. Rios-Vazquez ${ }^{2}$ \\ ${ }^{1}$ Department of Administrative Sciences, Sonora Institute of Technology, Cd. Obregon, Sonora, Mexico \\ ${ }^{2}$ Department of Industrial Engineering, Sonora Institute of Technology, Cd. Obregon, Sonora, Mexico \\ Correspondence: Alejandro Arellano-Gonzalez, Department of Industrial Engineering, Sonora Institute of \\ Technology, Av. Antonio Caso 2266, Villa Itson, Ciudad Obregon, Sonora, Mexico, C.P. 85130. Tel: \\ 52-644-410-90-00 ext. 1748. E-mail: alejandro.arellano@itson.edu.mx
}

\author{
Received: January 20, 2017 \\ Accepted: March 2, $2017 \quad$ Online Published: March 26, 2017 \\ doi:10.5539/ijbm.v12n4p55 \\ URL: https://doi.org/10.5539/ijbm.v12n4p55
}

\begin{abstract}
The objective of this research is to analyze the influence of strategic management on competitiveness and organizational performance, an issue that is present in micro, small and medium-sized enterprises in the food and beverage preparation industry of the service sector. The study sample was of 200 Mexican organizations from Ciudad Obregón, Sonora. The results indicated that strategic management has a positive, direct and significant effect on competitiveness. The results that were obtained by means of linear regression analysis make it possible to assert that the interaction between both variables (strategic management and competitiveness) establishes significant differences in the levels of organizational performance. It was concluded that the enhancement of strategic management contributes to the increase in organizational performance. Therefore, a joint intervention must take place on strategic management and competitiveness.
\end{abstract}

Keywords: strategic management, competitiveness, organizational performance

\section{Introduction}

Nowadays, a complex entrepreneurial dynamic may be observed despite an increase in the incorporation of micro, small and medium-sized enterprises (MSMEs); these have expanded due to the government support that has promoted their creation to generate economic growth and reduce poverty in Mexico. Thus, it is important that entrepreneurs adopt the necessary tools and knowledge that lead action towards the accomplishment of favorable organizational performance. Several research studies, according to Mora, Vera and Melgarejo (2013), have shown that MSMEs undergo problems that affect the achievement of good organizational performance, in addition to favorable competitive levels. Among them is the lack of strategic management implementation, an important aspect in the future growth process of these enterprises, as it enables them to coordinate actions that must be carried out day by day to achieve medium and long term objectives (Lizardi, Ríos, Coronado, Lee and Ortiz, 2014; Tomasso, Marco, \& Dubbini, 2000).

As reported by the Ministry of Economy ME [Spanish](2013), MSMEs are business units that have between 10 and 50 employees, or that generate annual sales of more than 4 and up to 100 million pesos. They are independent entities that are aimed at producing and transforming goods, as well as providing services to satisfy the needs of their clients.

Based on data by the ME (2009), the MSMEs in Mexico represent more than 3\% of total enterprises, and almost $15 \%$ of the employees in the country; moreover, they produce more than $14 \%$ of the Gross Domestic Product (GDP) [Spanish]. Regarding financial support, Observatorio PYME [Spanish] states that within Mexican MSMEs there is unawareness of public programs, pointing out that $86 \%$ of businesses do not know about the federal, state and municipal support programs, and that only $12.65 \%$ of these are familiar with them, but have never used them (Flores \& Flores, 2009).

The state of Sonora, which has a diversity of economic activities, showing their wealth in natural resources along with its important industrial activity, mainly centered in the trade and service sector. The current situation of 
MSMEs in the state of Sonora is not very different from that of the rest of the country. Nevertheless, the MSMEs in the service sector dedicated to food and beverage preparation in the urban zone of the south of Sonora and northwest of Mexico, have gained importance according to data from the National Institute of Statistics and Geography INEGI [Spanish] (2009), indicating that they contribute with the $17.56 \%$ of the state GDP.

It is important to mention that a study carried out by Ochoa, Morales and Yepiz (2012), has pointed out that the fact that MSMEs in the region do not have specific strategies oriented towards better development conditions; they lack trained personnel and alternative action plans; they do not have clearly stated strategies; and they cannot afford to hire administration consultancy services. In addition, Miranda (2012), argues that the business sector in the south of the state - specifically in the municipality of Cajeme- has not had the proper vision to consolidate businesses and make them grow; therefore, the lack of vision of the local business people has prevented them from identifying and taking advantage of available opportunities regarding free trade agreements, and thus, numerous enterprises have gone out of business and others are barely surviving. There is a great variety of producers, merchants and service providers that have made their shortcomings evident in the way they lead their organizations, which limits their competitiveness; in addition, there is deficient management with respect to the quality of products and services (Miranda, 2012).

Therefore, these deficiencies impel towards the development of a research that is focused towards the review of the management of competitive factors that are put into practice, in addition to the application of the strategic management that they entail to determine the type of organizational performance that will have the Mipymes of the services sector. Therefore, the objective of this research is to analyze the influence of strategic management on the relationship between competitiveness and organizational performance, in the MSMEs of the food and beverage preparation service sector, especially when there is evidence of poor management. To answer the research question, does strategic management generate positive change in the relationship between competitiveness and organizational performance?

The following hypothesis formulated for the present study:

$\mathrm{H}_{3}$ : Strategic management presents a moderating positive effect in the relationship between competitiveness and organizational performance, such that MSMEs with high strategic management significantly increase their organizational performance level in the presence of an increase in competitiveness related to the MSMEs with low strategic management.

To achieve this goal, the study arises from the hypothesis which states that strategic management exerts influence in the relationship between competitiveness and organizational performance in MSMEs of the service sector in Mexico. The work begins with a description of MSMEs in the country and in the state of Sonora; it later presents a theoretical revision of the models related to the study of business competitiveness, organizational performance, and strategic management as pivots in the creation of problem solutions which impact MSMEs. The third section describes the methodology considered for the process of study results. Lastly, in the fourth section, there is a discussion on these results, and it ends with conclusions and an analysis of the implications for future research areas.

\section{Conceptual framework}

\subsection{Competitiveness}

As a study variable, competitiveness may be observed from different perspectives. Numerous authors strive in the analysis of business competitiveness as a focal point in the performance of local and international markets, regardless their geographical location. From the perspective of Solleiro and Castañón (2005), business competitiveness is the capacity of an organization to maintain or increase its market share, based on strategies that have to do with the increase in productivity entrepreneurial capacity among businesses in a competitive environment that is determined by the consumer sector and market, and as the policies set by national governments and regional economic alliances.

Competitiveness is a fundamental element for MSMEs to keep comparative advantages that allow them to enjoy and maintain an outstanding position in the socio-economic environment in which they perform. In relation to this, Moreno (2008) defines competitive advantage as the skills, resources, knowledge, attributes, etc., set out by an organization and which its competitors lack, thus making them obtain higher profits. Conversely, Porter's concept of competitiveness (2008) is relative, as it shows a comparative position of enterprises when utilizing the same reference measurements. It can be said that it is a concept that is still under development, and in accordance to the dimension that the organization systems belong to as well as the indicators by which they are measured. Michael Porter suggests a conceptual framework for defining competitive advantage in the business 
field (generic value production chain), the industrial field (the five determining factors of sector engagement) and the national field (the diamond of the national competitive advantage).

To talk about business competitiveness, according to Saavedra (2012), the enterprise must consider the environment factors that affect the organization; and, in order to do so he suggests a methodology that allows detecting the company level by the areas related to competitiveness, based on both internal and external criteria. This and other similar definitions lead to affirm that enterprise competitiveness is associated to whatever takes place externally (governmental policies, economic structure of the country, market characteristics, regional variables) and internally (market, technology, innovation, product quality and service, human resources, culture, legal regulations) in the organization, but depends closely on the internal performance of the same entity. Thus, strategic management is a fundamental factor to reach a dominant and successful position in the markets.

In reviewing the state-of-art international and Latin-American academic literature, there are different research works that suggest representative indicators for enterprise competitiveness of MSMEs (see Table 1).

Table 1. Enterprise Competitiveness Indicators

\begin{tabular}{|c|c|c|c|c|c|c|c|c|c|c|}
\hline Indicator/Author & $\begin{array}{l}\text { Rubio } \\
\& \\
\text { Aragón } \\
\text { (2006) }\end{array}$ & $\begin{array}{l}\text { Solleiro } \\
\& \\
\text { Castañón } \\
(2005)\end{array}$ & $\begin{array}{l}\text { OECD } \\
(1996)\end{array}$ & $\begin{array}{l}\text { Quiroga } \\
\text { (2003) }\end{array}$ & $\begin{array}{l}\text { Saavedra } \\
\text { 2012) }\end{array}$ & $\begin{array}{l}\text { De la Cruz } \\
\text { Morales \& } \\
\text { Carrasco } \\
(2006)\end{array}$ & $\begin{array}{l}\text { Gómez } \\
\text { (2003) }\end{array}$ & $\begin{array}{l}\text { López } \\
\text { 2012) }\end{array}$ & $\begin{array}{l}\text { Mosquera } \\
(2010)\end{array}$ & $\begin{array}{l}\text { Mora } \\
(2015)\end{array}$ \\
\hline Technology & $\mathrm{x}$ & $\mathrm{x}$ & & $\mathrm{x}$ & $\mathrm{x}$ & $\mathrm{x}$ & $\mathrm{x}$ & & $\mathrm{x}$ & \\
\hline Innovation & $\mathrm{x}$ & & & & & & $\mathrm{x}$ & $\mathrm{x}$ & $\mathrm{x}$ & \\
\hline Marketing & $\mathrm{x}$ & $\mathrm{x}$ & $\mathrm{x}$ & & $\mathrm{x}$ & $\mathrm{x}$ & & & $\mathrm{x}$ & $\mathrm{x}$ \\
\hline Human Resources & $\mathrm{x}$ & $\mathrm{x}$ & $\mathrm{x}$ & $\mathrm{x}$ & $\mathrm{x}$ & $\mathrm{x}$ & $\mathrm{x}$ & & $\mathrm{x}$ & $\mathrm{x}$ \\
\hline $\begin{array}{l}\text { Leading skills - } \\
\text { Strategic planning }\end{array}$ & $\mathrm{x}$ & & & $\mathrm{x}$ & $\mathrm{x}$ & & & & $\mathrm{x}$ & $\mathrm{x}$ \\
\hline Financial Resources & $\mathrm{x}$ & $\mathrm{x}$ & & $\mathrm{x}$ & $\mathrm{x}$ & $\mathrm{x}$ & & & $\mathrm{x}$ & $\mathrm{x}$ \\
\hline Culture & $\mathrm{x}$ & & & & & & $\mathrm{x}$ & $\mathrm{x}$ & & $\mathrm{x}$ \\
\hline Quality & $\mathrm{x}$ & & & $\mathrm{x}$ & $\mathrm{x}$ & & $\mathrm{x}$ & $\mathrm{x}$ & & $\mathrm{x}$ \\
\hline Production & & $\mathrm{x}$ & $\mathrm{x}$ & $\mathrm{x}$ & $\mathrm{x}$ & $\mathrm{x}$ & & & $\mathrm{x}$ & \\
\hline Logistics & & & & & $\mathrm{x}$ & $\mathrm{x}$ & & & $\mathrm{x}$ & \\
\hline Internal Organization & & $\mathrm{x}$ & & $\mathrm{x}$ & & & & & & \\
\hline Purchases & & $\mathrm{x}$ & $\mathrm{x}$ & $\mathrm{x}$ & $\mathrm{x}$ & & & & $\mathrm{x}$ & \\
\hline Research and & & $\mathrm{x}$ & $\mathrm{x}$ & $\mathrm{x}$ & & & & & & \\
\hline \multicolumn{11}{|l|}{ Development } \\
\hline Client- Provider & & $\mathrm{x}$ & $\mathrm{x}$ & & $\mathrm{x}$ & & & & & \\
\hline \multicolumn{11}{|l|}{ Interaction } \\
\hline Legal Regulations & & & & & & & $\mathrm{x}$ & $\mathrm{x}$ & $\mathrm{x}$ & $\mathrm{x}$ \\
\hline
\end{tabular}

Note: Created by authors based on Saavedra (2012).

Table 1 identifies possible enterprise analysis areas or competitiveness indicators, from which there is a proposal to utilize a quantitative instrument to evaluate the level of competitiveness perceived by the administrators of each organization. This specific instrument is presented as a structured questionnaire, with a scale-type response format that enables understanding on how management visualizes the competitive level reached by the entity with regards to other organizations in the region.

\subsection{Organizational Performance}

Organizational performance has several definitions. For example, Gopalakrishnan (2000) associates performance with efficiency, efficacy, financial outcomes and employee satisfaction. On the other hand, Olson, Slater and Hule (2005) suggest a global measurement for organizational performance outcomes based on the performance perceived with respect to the enterprise and its competitors. Moreover, they indicate that by means of perceived performance it is possible to cover not only quantitative but also qualitative results which would be important for the organization.

Enterprise performance can be measured by using quantitative and qualitative indicators since both integrate the evolution of several business variables, as it has been stated by Aragón (2004). At a quantitative level in the literature by Sánchez and Aragón (2003), performance has been measured in different ways, such as via financial 
measures in the revision of the business return over investment (ROI); for Carpenter and Sanders (2002), it is related to the return over assets (ROA) and business profitability (Desphandé et al., 1993; Hill \& Jones, 2005); or financial benefits (Aragón et al., 2003) and market measures, such as sales growth (Mayondo \& Farell, 2003).

Now, at qualitative level, there are different performance measurements such as the efficacy measurement in organizations. This measurement was defined by Quinn and Rohrbaugh (1983), as a construct associated with different organization analysis models; one of the models is called internal process, which consists in improvements in the internal processes coordination, in personal tasks organization and in the product quality. Another model is that of the open system, which consists in the increase of client satisfaction, in the ability to adapt to the changing market needs, and in the company image and its products. There is also a rational model, which deals with the increase in the market quota, profitability and productivity. Lastly, the model of human relationships consists in the increase in the workers' motivation, and the reduction of desertion and absenteeism.

It should also be mentioned that authors Gupta and Govindarajan (1984) proposed 13 dimensions in organizational performance which include sales, growth rate, market proportion, operational profitability, sales profitability, operations cash flow, return over investment, the development of new products, markets development, innovation and development activities, cost reduction programs, and the development of personnel, as well as political and public issues; within these are also financial measures, as it has been previously mentioned.

In accordance with what has been revised in literature and according to the model that has been taken as a reference in the present research, organizational performance will be measured based on contributions by Gitman (1997), and Brealey \& Myers (1998), through quantitative indicators, focusing on the financial aspect of the organization such as the company profitability compared to that of its competitors and the earnings of the last year.

\subsection{Strategic Management}

The term management comes from the business sector which is integrated in MSMEs in issues that refer to attributes for administration and management. Currently, the term management in some research such as that conducted by Whetten and Cameron (2011), and Isaacs \& McAllister (2013), refer to understanding the dynamic, responsible and proactive execution of processes to reach expected outcomes.

For this study, it is necessary to incorporate the term strategic to that of management to contribute to the achievement of enterprise competitiveness impacting on performance Harris, Graham, Reid, McElroy and Hamby (1994). Athanassiou et al. (2002), in a study performed with 42 Mexican companies and 201 managers, these authors found significant relationships among the group's strategic behavior and the companies' founders.

From another point of view, and under an analytical perspective, it is important to point out at a global scale, that regarding the term strategic management, there is currently an intense conceptual debate, as well as economic policies, regarding MSMEs because their socio-economic and territory relevance has been acknowledged, as pointed out by Tomasso, Marco \& Dubbini (2000), to such an extense that its discussion has become an interesting study topic; the aforementioned is due to the fact that these organizations are the ones that satisfy the needs of certain markets for which the great corporations have no interest owing to their small size, but which are founded by great entrepreneurs and business people.

The foregoing is related to the authors Kaplan \& Norton (1992), as both created a new management system, where enterprise strategic objectives have been transformed in a balanced set of indicators. The purpose of this system has been to balance enterprise financial and non-financial measures. This has been referred to as the Balanced Scorecard - BSC, and it is considered as one of the 75 most influential business ideas of the $20^{\text {th }}$ century, as stated by Harper, Man, Taylor \& Niven (2005). Today, the knowledge acquired by employees, the relationship with clients, the fostering of innovation and change lead to success, where this success may be generated by active enterprises that can be measured in a balanced way.

Therefore, strategic management in MSMEs, viewed under one perspective, may represent an important alternative in the development of processes that support the development of a competitive organization. Regarding this, Kaplan \& Norton (2008) have indicated that it is essential to have a strategy to guide company managers and key staff towards the achievement of medium and long term objectives, as they are the central axis by which day to day activities are attuned in the different departments of an organization. Considering the above, the development and strengthening of new planning strategies for the MSMEs in the country are fundamental since they will allow them to gain exposure and generate actions to increase competition against the international market, as well as help them not only maintain the market they currently have, but also increase their 
organizational performance.

Along the same line, this research intends to identify the influence of strategic management in relation to competitiveness and organizational performance of MSMEs of the service sector dedicated to food and beverage preparation in the northwest of Mexico.

\section{Method}

\subsection{Participants}

The participants were selected by sampling for convenience, which comprised MSMEs managing business owners of the service sector dedicated to food and beverage preparation, located in the northwest of Mexico. The sample number of 200 MSMEs was obtained through data provided by the National Statistics Directory of Economic Units (DENUE, 2016). A total of 200 surveys were allocated with a response rate of $100 \%$. Some of the main characteristics of these entrepreneurs is that they are in average 43.6 years old, have been operating this type of business for an average of 12.2 years, and the businesses have been open for an average of 11.09 years; in addition, $115(57.5 \%)$ of the surveyed were men and $85(42.5 \%)$ were women; another interesting data is that $143(71.5 \%)$ of the people surveyed are married and the remaining $57(28.5 \%)$ are single; of these, 157 (78.5\%) have children and the remaining $43(21.5 \%)$ do not. With respect to the size of the company $195(97.5 \%)$ is small and $5(2.5 \%)$ medium company, clarifying that they are within the category of 10 to 50 employees. The other characteristics are classified as shown on table 2.

Table 2. Characteristics of the managing business owners who participated in the study $(\mathrm{N}=200)$

\begin{tabular}{lll}
\hline Characteristics & $N$ & $\%$ \\
\hline Level of Education & & 50.5 \\
Bachelor Degree & 101 & 40 \\
High School & 80 & 8 \\
Middle School & 16 & 1.5 \\
Elementary School & 3 & 54 \\
Type of Administration & & 46 \\
Family Run & 108 & 46
\end{tabular}

Note: The data was obtained through information collected from the responses in the measurement instrument given by administrative managers (staff).

\subsection{Measurement Instrument}

A four-section measurement survey was used: the first one is related to socio-demographic data; the second one measures competitiveness; the third, organizational development; and the last part strategic management. This instrument was answered by a Likert type scale with five options to answer, from 1 (Totally disagree) to 5 (Strongly agree), where the highest punctuations indicate the greatest level of agreement. Experts from every field of study were consulted to conduct the measurement instrument.

To measure competitiveness, there were nine items based on several authors, such as: Aragón \& Rubio (2005), Gómez (2003), Kalleberg \& Leicht (1991), López (2012), Mora (2015), Mosquera (2010), Porter (1985), and Saavedra (2012).

Regarding organizational performance, there were two items used which were focused on financial aspects, such as organization profitability in comparison with that of its competitors, and the profits from the previous year, based on contributions by Gitman (1997), and Brealey \& Myers (1998); to measure strategic management, five items were included based on contributions made by Kaplan \& Norton (1996).

As a result of the content validation process, 42 of the original suggested items at the beginning of the application tool design were eliminated after performing revision tests of the correlation among the three study variables; the aforementioned are presented in table 3, which shows that the median score of the MSME results vary from high level to very high level at 4.20 . This result confirms the perception of those surveyed on the usefulness of the study model. The standard deviation for the MSME variables resulted in .973, which reflects 
the existence of a considerable variability within the data set. Nevertheless, several values indicate that the answers to the study variables differ from one person to another, which means that there is a tolerable variation in the answers. To measure competitiveness, there were 37 initial items proposed, 4 items regarding organizational performance, and 19 items related to strategic management. However, once the test was given of exploratory factor analysis, it was reduced to a total of 16 items (see Table 4), where nine items remained for competitiveness, two items for organizational performance, and five items for strategic management.

Table 3. Descriptive Statistics of all the main constructions $(\mathrm{N}=200)$

\begin{tabular}{|c|c|c|c|c|c|c|}
\hline Variable & Total items & Minimum & Maximum & Median & $\begin{array}{l}\text { Standard } \\
\text { Deviation }\end{array}$ & Level \\
\hline Competitiveness & 37 & 1 & 5 & 3.96 & .970 & M \\
\hline Organizational Performance & 4 & 1 & 5 & 4.20 & .765 & M \\
\hline Strategic Management & 19 & 1 & 5 & 4.01 & .973 & M \\
\hline
\end{tabular}

Note. The table shows the number of items per variable, its medians and the signified results of the standard deviation; data obtained based on statistical calculations to obtain the results.

As shown on table 3, 200 valid cases of the median and standard deviation for all the variables were analyzed. The interval scales of five points were classified into categories of the same size: low level, moderate low, moderate high and very high. The criteria of Md Isa (2007) was considered to measure the level column in table 3 , in which median punctuations of less than 3.00 were considered low (L), median punctuations of 3 to 5 were considered moderate $(\mathrm{M})$, and the median punctuations of more than 5 were considered high $(\mathrm{H})$. Overall, the results in table 3 show that the variables are relatively moderate and above (3.00), and that the surveyed paid more attention to the relationship between strategic management and organizational performance of the MSMEs. More specifically, the highest punctuation was for organizational performance. (4.01).

In table 3, organizational performance seems to have the least standard deviation (.765), which could be due to several reasons: (1) the people surveyed did not understand the statements related to organizational performance in the questionnaire, (2) the people surveyed were not sure of the role of performance in the functioning of MSMEs, and (3) the people surveyed could have similar points of view or perceptions on the influence of performance in MSMEs productivity.

As a result of the content validation process, reliability is described as the measurement consistency or the level at which an instrument measures in the same way every time it is used to measure the same construct (Nunnally, 1978). In this study, the SPSS program was used to determine the internal consistency of constructions. The instrument was tested through the Cronbach alpha values in SPSS 21, after which the reliability obtained was approximately .600, which is considered as an acceptable value according to Hair, Anderson, Tatham and Black (1999). Table 4 indicates that all the reliability coefficients varied from .830 up to .950 . An integrated reliability index higher than .700 shows a satisfactory internal consistency as explained.

Table 4. Cronbach's alpha for the study variables

\begin{tabular}{|c|c|c|c|c|}
\hline Variable & Total Items & Items after & EFA & Cronbach's Alpha after EFA \\
\hline Competitiveness & 41 & 9 & & .950 \\
\hline Organizational Performance & 4 & 2 & & .830 \\
\hline Strategic Management & 20 & 5 & & .926 \\
\hline Total Items & 65 & 16 & & \\
\hline
\end{tabular}

Note: The above table shows information obtained from the statistical calculations carried out with respect to the coefficient that measures the tool reliability.

In the above table, the Cronbach's alpha figures indicate the reliability coefficients of all the variables of the study that comply with the current study objectives, for which it was necessary to revise the frequencies, the lost values, besides the items behavior where they had to be readjusted, eliminating 49 of them: 32 were related to competitiveness, 2 regarding organizational performance, and 15 strategic management.

To validate the construct, an exploratory factorial analysis was conducted with the Oblimin rotation method (delta equal to zero) and maximum authenticity extraction. The data proved its suitability for this type of model, 
which was demonstrated in the significance of Bartlett's test of sphericity (Martínez, Hernández, \& Hernández, 2006). For the suitability test, a Kaiser-Meyer-Olkin (KMO) sampling suitability measurement was utilized. As indicated in table 5, statistical results show suitability to the model. As an inclusion approach for the items, these had to have a factor load of 0.30 or more, which reflects the theoretical soundness the item (Hair, Anderson, Tatham, \& Black, 1999; Martínez, 2009).

Table 5. Sample suitability measurement

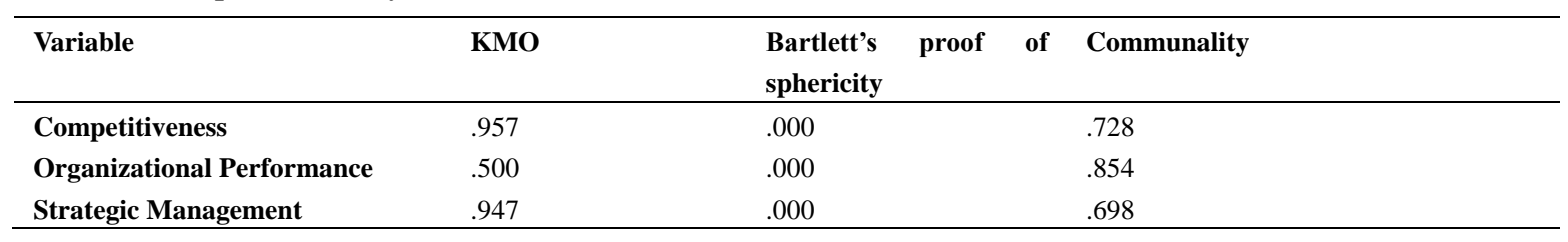

Note: The table above shows information obtained from statistical calculations carried out regarding the factor analysis through the Kaiser-Meye-Olkin (KMO) sample suitability measurement.

It can be proven, based on the results shown in this table, that the sampling suitability of this analysis is not only desirable but it also offers good data suitability, given that the KMO statistics indicate the variation ratio that the analyzed variables have in common, indicating a .957 value for competitiveness, .500 for organizational performance, and .947 for strategic management; this indicates a coefficient that is very close to the unit, the most recommended according to what is dictated by literature (greater than .05 for this type of analysis); thus, it represents a perfect data suitability for the factor analysis model. By means of Bartlett's test of sphericity it can be ensured that if the critical levels are higher than .05 for all the variables, the nule sphericity hypothesis cannot be rejected.

\subsection{Procedure}

The objective of the study was explained to the managing business owners, and their authorization was requested to conduct the study. Once consentment was obtained, the measurement tool was administered to the business owner, guaranteeing confidentiality in handling the information they provided.

The following indications were set forth in analyzing the instrument: (a) content validity as per expert judgement, (b) construct validity through exploratory factor analysis, and (c) reliability, determined by internal scores consistency. For the descriptive and inferential statistical analysis, a Statistical Package for Social Sciences was used (SPSS) in its $21^{\text {st }}$ version.

\section{Results}

To respond to the study presented about the correlation between the study variables, the method proposed by the author Pearson (1900) was taken into consideration for calculating the criteria.

Table 6. Correlations between variables

\begin{tabular}{|c|c|c|c|c|}
\hline & & \multicolumn{3}{|c|}{ Correlations } \\
\hline & & Competitiveness & Performance & Strategic Management \\
\hline \multirow[t]{3}{*}{ Competitiveness } & Pearson's Correlation & 1 & $.509^{* *}$ & $.714^{* *}$ \\
\hline & Sig. (bilateral) & & .000 & .000 \\
\hline & $\mathrm{N}$ & 200 & 200 & 200 \\
\hline Organizational & Pearson's Correlation & $.509^{* *}$ & 1 & $.554^{* *}$ \\
\hline \multirow[t]{2}{*}{ Performance } & Sig. (bilateral) & .000 & & .000 \\
\hline & $\mathrm{N}$ & 200 & 200 & 200 \\
\hline Strategic & Pearson's Correlation & $.714^{* *}$ & $.554^{* *}$ & 1 \\
\hline Management & Sig. (bilateral) & .000 & .000 & \\
\hline
\end{tabular}

In table 6, the correlation patterns may be observed in which the outcomes resulted as expected, derived to the results obtained, where competitiveness obtained a positive and significative correlation with organizational 
performance $(r=.509, \mathrm{p}<.001)$. As far as the correlation between strategic management and performance $(r$ $=.554, \mathrm{p}<.001)$, the results were also significative and positive.

The results in Table 6 clearly show the existence of a significant and positive correlation for each case.

Continuing the above, a linear regression analysis was performed using the Stepwise method between the two variables, to determine if the strategic management influences the relationship between competitiveness and organizational performance of the MSMEs of the sample. The findings were positive and statistically significant, with strategic management a variable that accounts for $32 \%$ of the variance of the variables competitiveness and organizational performance (see Table 7).

Table 7. Linear regression analysis to prove the moderating effect of strategic management in the relationship between competitiveness and organizational performance

\begin{tabular}{lll}
\hline Predicting step & $\mathbf{R}^{2}$ & $\boldsymbol{\beta}$ \\
\hline Strategic Management & .32 & $.55^{* * *}$ \\
$\mathbf{N}$ & 200 & \\
\hline
\end{tabular}

Note: The above table shows the results obtained from a linear regression calculation to prove the moderating effect of strategic management in the relationship between competitiveness and organizational performance. $* \mathrm{p}<.10 . * * \mathrm{p}<.05 . * * * \mathrm{p}<.001$.

The moderating model equation is represented as follows:

$$
\mathrm{DO}=\beta 0+\beta 1 \mathrm{GE}+\beta 2 \mathrm{Ci}+\beta 3 \mathrm{GE} \times \mathrm{Ci}+\varepsilon
$$

Where:

$\mathrm{DO}=$ Organizational performance

$\beta 0=$ Measurement of the existing relationship between two variables. Their value is between $-1 \mathrm{y} 1$. If it is negative, the relationship between the variables is inverted, that is, as values increase on one they decrease on the other. A value of zero indicates the lack of relationship. When the variables are continuous and have a linear relationship, Pearson's linear correlation coefficient is a proper association measurement. When the variables are not continuous, other correlation coefficients are used.

$\mathrm{GE}=$ Strategic management

$\mathrm{C}=$ Competitiveness

$\mathrm{i}=$ Factors of each of the variables to be analyzed

$\varepsilon=$ Error term

Therefore, with the analysis of multiple linear regression, hypothesis 3 was proved, and if it is possible to reject the hypothesis that the coefficient be zero o negative, it could be affirmed that the impact of strategic management in relation to the influence of competitiveness with organizational performance is greater the more it interacts with competitiveness.

\section{Discussion}

The objective of the study was to identify the moderating effect of strategic management in the relation between competitiveness and organizational performance. As predicted, the presence of strategic management encourages the development of competitiveness (H1). In other words, competitiveness may be increased as long as the enterprise administrator implements strategic management in the organization. In addition, the MSME's with favorable organizational performance develop more strategic management levels (H2).

On the other hand, the linear regression analysis used to prove the moderating effect of strategic management allows us to state that when both variables are combined (competitiveness and strategic management), the results enhance organizational performance (Cuba, Decenzo, \& Anish, 1983; Johnson \& Storey, 1993); and in situations where the administrators perceive high levels of strategic management, individuals demonstrate more competitiveness.

The findings confirm the theory which states that in the presence of strategic management there is a favorable level of competitiveness, and thus, an optimal organizational performance (Athanassiou et al., 2002; Harris et al., 1994; Upton et al., 2001).

Strategic management is the process by which administrators or leaders at organizations align objectives with 
actions that are to be developed in time. In fact, the concept is clearly linked to competitiveness since both allocate a sequence of actions that are ordered in a timeline, in such a way that one or several objectives may be reached by accomplishing the desired organizational performance in terms of profitability.

Considering the above, the theory posed by Kaplan \& Norton (1996), is of great importance for the development and strengthening of new planning strategies for MSMEs in Mexico, since if it were put into practice it would allow such enterprises to make a mid and long term impact, generating actions to increase competitiveness in their local and regional markets, as well as to enable them not only to retain their current market, but also increase within new national and international markets. To achieve this, it is essential that they count on government and institutional support to guide and create MSMEs.

It is important to point out that the theoretical model stated herein may be a useful reference to guide the organizational maturity process, as it is evident that enterprises cannot evolve from a chaotic low productivity situation with processes out of control, to another that is defined by its order, standardization, and productive articulation.

An additional contribution of the study is to have carried out a study including three variables such as strategic management, competitiveness and organizational performance, for Mexican service MSMEs in Ciudad Obregón, Sonora. Nevertheless, it would be an enriching experience to apply it in other contexts for future research.

\section{Managerial implications}

The nature of organizations' processes, specifically MSMEs, is fundamentally changing. Globalization, privatization and the corresponding emphasis on competitiveness, as well as performance in organizations, have an overall influence on enterprises and the work experiences of business administrators and leaders.

Thus, organizations and their leaders must collaborate find ways to respond to the new scenarios at the workplace, to provide meaning and value in the achievement of the established short, medium and long-term goals.

With this study it may be concluded that in potentiating strategic management there is a contribution towards diminishing the problems that MSMEs face regarding their competitiveness and organizational performance.

Therefore, it is important to intervene on the administrator and the enterprise director through the strengthening of their leadership skills, and at the same time improve the environment, by allocating a budget for the same, but mainly, by manifesting the willingness of leaders to carry out interventions that are oriented towards the improvement of organizational performance.

In other words, as pointed out by Kaplan \& Norton (2008), it is not enough to focus on the factors that integrate strategy and operations to achieve a competitive edge; it is essential to count on a strategy to guide enterprise directors and key personnel on the right path to reach the short, medium and long-term goals in order to improve organizational performance, the life cycle of the enterprise, and mainly, the well-being of employees and the country in general. The promotion and programs at organizational level are also imperative, which should comply with two requirements: (1) increase the availability of resources (financial, human and technological) to promote enthusiasm and commitment, and (2) organization leaders and those of human resources management must strategically collaborate in the design of a comprehensive staff management system, in compliance with the legal regulations that provide safety to both the personnel and the enterprise itself. In essence, the challenge is to identify the requirements needed to align and bring together organizational success and enterprise-employee well-being.

\section{Conclusion}

The objective of the present investigation was to describe and determine if the strategic management generates influence in the relationship between competitiveness and organizational performance by the Small Business of service incubated in the south of the state of Sonora, Mexico. The findings of the study suggest a significant relationship and prediction between both variables, being able to verify with this the research hypothesis.

It is important to note that SOEs should work in the application of strategic management practices as noted by Kaplan and Norton in order to achieve a level of competitiveness and organizational performance. Therefore, MSMEs must begin to develop managerial skills, because business leaders are responsible for sustaining organizations (Teece, 2000; Zott, 2003) with qualified staff and greater learning ability, which provide value Consumers and stakeholders.

On the other hand, based on the literary revision and the results obtained in this research, it is recommended the realization of new researches that contemplate the study of dimensions as leadership in relation to intellectual 
capital (Kamukama, 2013) as part of the competitiveness. In addition, it would be interesting to carry out a study where a gender comparison was made in relation to management practices, competitiveness and organizational performance. As a conclusion, the present report contributes to the knowledge on the subject in the country, and in particular, it provides evidence regarding the MSMEs of southern Sonora.

\section{References}

Aragón, A. (2004). Gestión de la formación en la empresa [Training management in the company]. Formación y cultura empresarial en la empresa española [Training and business culture in the Spanish company]. Madrid, Spain: Cívitas.

Aragón, A., Barba, A. \& Sanz, V. (2003). Effects of training on business results. International Journal of Human Resources Management, 14, 956-980. http://dx.doi.org/10.1080/0958519032000106164

Athanassiou, N., W. Crittendon, L. Kelley y P. Márquez. (2002). Founder centrality effects on the Mexican family firm's top management group: firm culture, strategic vision and goals, and firm performance. Journal of World Business, 37 (2), 139-150. http://dx.doi.org/10.1016/S1090-9516(02)00073-1

Brealey, R. \& Myers, S. (1998). Principios de finanzas corporativas [Principles of corporate finance]. McGraw Hill.

Camisón, Z. (2001). La investigación sobre la pyme y su competitividad. Balance del estado de la cuestión desde las perspectivas narrativa y meta-analítica [Research on SMEs and their competitiveness. Balance the state of the issue from the narrative and meta-analytic perspectives]. Papers of Spanish Economy, 89(90), 43-83.

Carpenter, M., \& Sanders, W. (2002). Top management team compensation: The missing link between CEO pay and firm performance? Strategic Management Journal, 23(4), 367-375. https://doi.org/10.1002/smj.228

Cuba, R., Decenzo. D., \& Anish. A. (1983), Management practices of successful female business owners. American Journal of Small Business, 8(2), 40-45.

De la Cruz, I., \& Morales, J. (octubre de 2006). En las memorias del X/ Foro de Investigación. Desarrollo de competencias en la Micro, Pequeña, Mediana y Gran empresa en México: Un estudio empírico exploratorio [In the memoirs of the X / Research Forum. Micro, Small, Medium and Large Enterprise Competence Development in Mexico: An exploratory empirical study]. International Congress of Accounting, Administration and Informatics, Mexico.

Deshpande, R., Farley, J., \& Webster, F. (1993). Corporate Culture, customer orientation, and innovativeness in Japanese firms: a quadrad analysis. Journal of Marketing, 57, 23-37. https://doi.org/10.2307/1252055

Flores, I., \& Flores, R. (2009). Políticas públicas en apoyo a las micro, pequeñas y medianas empresas en México [Public policies in support of micro, small and medium enterprises in Mexico]. Second UAM forum for the study of micro, small and medium enterprises, Mexico.

Gitman, L. (1997). Fundamentals of Financial Management.. México: Harla, S.A.

Gómez, G. (2003). Análisis competitivo de las pequeñas y medianas empresas panificadoras del Distrito Federal en su entorno Agroindustrial: trigo, harina, panificacion [Competitive analysis of the small and medium-sized bakery companies of the Federal District in their Agroindustrial environment: wheat, flour, baking] (Master's thesis). UNAM, México D.F.

Gopalakrishnan, S. (2000). Unravelling the links between dimensions of innovation and o ganizational performance. The Journal of High Technology Management Research, 11(1), 137-53. http://dx.doi.org/10.1016/S1047-8310(00)00024-9

Gupta, A., \& Govindarajan, V. (1984). Business unit strategy, managerial characteristics and business unit effectiveness at strategy implementation. Academy of Management Journal, 27(1), 25-41.

Hair, J., Anderson, R., Tatham, R., \& Black, W. (1999). Análisis Multivariante. Madrid: Prentice-Hall.

Harper, G., Man, L. H., Taylor, S., \& Niven, S. (2005). Factors associated with offending. In G. Harper and C. Chitty (Eds.), The impact of corrections on re-offending: A review of what works (3rd ed., pp. 17-29). London: Home Office Research, Development and Statistics Directorate.

Harris, K. R., Graham, S., Reid, R., McElroy, K., \& Hamby, R. (1994). Selfmonitoring of attention versus self-monitoring of performance: Replication and cross-task comparison. Learning Disability Quarterly, 17, 121-139. https://doi.org/10.2307/1511182

Hill, C., \& Jones, G. (2005). Administración estratégica: Un enfoque integrado [Strategic management: an 
integrated approach]. México: McGraw-Hill.

http://dx.doi.org/10.1108/15365430380000516

Isaacs, S., \& McAllister, J. (2013). Management Skills. University of Kentucky.

Johnson, S., \& Storey, D. (1993). Male and Female Entrepreneurs and Their Businesses, in S. Allen and C. Truman, eds. Women in Business: Perspectives on Women Entrepreneurs. London: Routledge.

Kalleberg, A. L., \& Leicht, K. T. (1991). Gender and Organizational Performance: Determinants of Small Business Survivial and Success. Academy of Management Journal, 34(1), 136-161.

Kaplan, R., \& Norton, D. P. (2008). The Execution Premium. Integrando la estrategia ylas operaciones para lograr ventajas competitivas. Barcelona: Planeta de Agostini.

Kaplan, R., \&. Norton, D. (1996). The Balanced Scorecard: Translating Strategy into Action. Boston: HBS Press.

Lizardi, M., Ríos, N., Coronado, E., Lee, E., \& Ortiz, P. (2014). Productividad en relación al género en las PYMES del subsector restaurantero en Cd. Obregón. Sonora. Equidad de género: Experiencias e investigaciones [Productivity in relation to gender in SMEs of the subsector restaurant in Cd. Obregón, Sonora. Gender equity: Experiences and research].México: Instituto Tecnológico de Sonora.

López, V., \& Marín, E. (2012). Ergonomía y Productividad: variables que se relacionan con la competitividad de las plantas maquiladoras. Ingeniería Industrial [Ergonomics and Productivity: variables that relate to the competitiveness of maquiladora plants. Industrial engineer]. News and New Trends, 9(23) 23-32.

Martínez, M., Hernández, M., \& Hernández, M. (2009). Psicometría [Psychometry[. Madrid: Alianza.

Mayondo, F., \& Farrell, M. (2003). Cultural orientation: Its relationship with market orientation, innovation and organizational performance [Cultural orientation: Its relationship with market orientation, innovation and organizational performance]. Management Decision, 41(3), 241-249.

Md Isa, M. (2007). Based SPWM Bridge Inverter. American Journal of Applied Sciences, 4(8), 584-586.

Miranda, C. (2012). Resultados mega, macro y micro de las empresas integradas al proyecto del Distrito Internacional de Agronegocios [Mega, macro and micro results of the companies integrated to the project of the International Agribusiness District]. México: Instituto Tecnológico de Sonora.

Mora, R., Vera, C., \& Melgarejo, M. (2015). Planificación estratégica y niveles de competitividad de las Mipymes del sector comercio en Bogotá[ Strategic planning and competitiveness levels of the MIPMEs of the commerce sector in Bogotá]. Management Studies, 31(134), 79-87. http://dx.doi.org/10.1016/j.estger.2014.08.001

Moreno, P. (2008). Desarrollo regional y competitividad en México, México, Cámara de Diputados. Centro de Estudios Sociales y de Opinión Pública [Regional development and competitiveness in Mexico, Mexico, Chamber of Deputies. Center for Social Studies and Public Opinion], (39), 1-45

Mosquera, A. (2010). Competitividad de la pequeña empresa del sector ornamentales en Atlixco [Competitiveness of the small ornamental sector in Atlixco, México]. Entramado, 6(2), 26-35.

National Institute of Statistic and Geography, INEGI. 2009. (Spanish)

Nunnally, J. C. (1978). Psychometric Theory. New York McGraw-Hill Book Company

Ochoa, B., Morales .L, Yepiz. K., \& Navarro E. (2012). Impacto en el sector empresarial y educativo de la asignatura de administración estratégica [Impact in the Business and educational sector of the subject of Strategic Administration]. México: Instituto Tecnológico de Sonora.

OECD (1996). Industrial Competitiveness: Benchmarking Business Environments inthe Global Economy. París.

Olson, E. (2005). The performance implications of fit among business strategy, marketing organization structure, and strategic behaviour. Journal of Marketing, 69(3), 49-65. http://dx.doi.org/10.1509/jmkg.69.3.49.66362

Porter, M. (1985). Competitive advantage. New York: Free Press.

Porter, M. (2008). The Global Competitiveness Report 2008-2009. Geneva, World Economic Forum.

Quinn, R. E., \& Rohrbaugh, J. (1983). A spatial model of effectiveness criteria: Towards a competing values approach to organizational analysis. Management Science, 29, 363-377. http://dx.doi.org/10.1287/mnsc.29.3.363 
Quiroga, D. (2003). Modelo matemático para determinar la competitividad de las Pymes. Cuadernos de Investigación y divulgación [Mathematical model to determine the competitiveness of SMEs. Research and Dissemination Papers]. Cali, Colombia: Corporación Universitaria Autónoma de Occidente.

Rubio, A., \& Aragón, A. (2006). Competitividad y recursos estratégicos en la Pyme [Competitiveness and strategic resources in SME]. Revista de Empresa [Business Review], 17, 32-47.

Saavedra, M. (2012). Una propuesta para la determinación de la competitividad en la pyme latinoamericana [A proposal for the determination of competitiveness in the Latin American SME]. Pensamiento \& Gestión [Thought \& Management], 33, 93-124.

Sánchez, G., \& Aragón, A. (2003). Top managers compensation, strategic orientations and firm performance: empirical evidence from Spanish firms. Management Research, 1, 27-44.

Solleiro, J., \& Castañón, R. (2005). Competitiveness and innovation systems: The challenges for México’s insertion in the global contex. Technovation, 45, 1059-1070. http://dx.doi.org/10.1016/j.technovation.2004.02.005

Teece, D. J. (2000). Managing Intellectual Capital. USA: Oxford University Press.

Tomaso, D., Marco, R., \& Dubbini, S. (2000). Towards a Theory of the Small Firm: Theoretical Aspects and Some Policy Implications. Desarrollo Productivo (CEPAL).

Upton, W. S. (2001). Business and Financial Reporting: Challenges from the New Economy, special report, Financial Accounting Standards Board,Norwalk, CT.

Whetten, D., \& Cameron, K. (2011). Developing management skills. New Jersey: Editorial Pearson.

Zott, C. (2003). Dynamic capabilities and the emergence of intra-industry differential firm performance: Insights from a simulation study. Strategic, Management Journal, 24(1), 97-125.

\section{Copyrights}

Copyright for this article is retained by the author(s), with first publication rights granted to the journal.

This is an open-access article distributed under the terms and conditions of the Creative Commons Attribution license (http://creativecommons.org/licenses/by/4.0/). 